\title{
Hubungan Kepatuhan Minum Obat dan Jumlah CD4 Terhadap Kualitas Hidup Orang dengan HIV AIDS di Poliklinik Voluntary Counseling and Testing RSUP Dr M Djamil Padang
}

\author{
Rihaliza ${ }^{1}$, Arina Widya Murni² ${ }^{2}$ Alfitri $^{3}$
}

\begin{abstract}
Abstrak
Infeksi Human Immunodeficiency Virus (HIV)/Acquired Immune Deficiency Syndrome (AIDS) merupakan salah satu masalah kesehatan masyarakat yang serius yang dapat menimbulkan masalah yang cukup luas yakni meliputi masalah fisik, sosial dan emosional. Permasalahan yang dihadapi oleh Orang Dengan HIV/AIDS (ODHA) akan mempengaruhi fisik dan psikologis ODHA itu sendiri sehingga akan berdampak terhadap kualitas hidup. Tujuan: Menganalisis hubungan kepatuhan minum obat dan jumlah CD4 terhadap kualitas hidup (ODHA) di Poliklinik Voluntary Counseling and Testing RSUP Dr. M. Djamil Padang. Metode: Jenis penelitian adalah analitik dengan pendekatan cross-sectional. Sampel penelitian berjumlah 100 ODHA yang melakukan kontrol di Poliklinik VCT RSUP Dr M Djamil Padang. Instrumen penelitian menggunakan 2 kuesioner, yaitu WHOQOL-HIV BREF, Simplified SelfReport Measure of Adherence dan studi dokumentasi pada rekam medis pasien. Analisis data menggunakan uji Chi square. Hasil: Analisis bivariat menunjukkan terdapat hubungan yang bermakna dengan $p<0,05$ antara kepatuhan minum obat dan jumlah CD4 terhadap kualitas hidup ODHA. Simpulan: Diharapkan kepada petugas kesehatan agar selalu memberikan edukasi tentang pentingnya patuh minum obat ARV secara rutin, sehingga jumlah CD4 di dalam darah berada dalam batas normal sehingga ODHA memiliki fisik sehat yang berdampak pada kualitas hidupnya.
\end{abstract}

Kata kunci: acquired immune deficiency syndrome, kualitas hidup, ODHA

\begin{abstract}
Human Immunodeficiency Virus (HIV / Acquired Immune Deficiency Syndrome (AIDS) is one of the serious public health problems that can cause extensive problems such as physical, social and emotional problems. The many problems is faced by People Living with HIVIAIDS (PLWHA) will affect their physic and psychologic, it will impact on the quality of life. Objectives: To analyzed the relationship between medication adherence and CD4 cell count on the quality of life of PLWHA in the Voluntary Counseling and Testing (VCT) of RSUP Dr. M. Djamil Padang. Methods: The type of research used was descriptive-analytic with cross-sectional approach. The samples of the study were 100 PLWHA who took control at the VCT Polyclinic of RSUP Dr. M. Djamil Padang. Research instruments were questionnaires, namely WHOQOL-HIV BREF, Simplified Self-Report Measure of Adherence and documentation study on patient medical records. Data analysis was using Chi-square test. Results: The bivariate analysis was a significant relationship with $p<0.05$ between adherence to taking medication and CD4 counts to the quality of life of PLWHA. Conclusion: It is expected that health workers always provide education about the importance of complying with routine ARV medication so that the CD4 cell count in the blood is within normal limits so that PLWHA have a healthy physique which consequently has an impact on their quality of life.
\end{abstract}

Keywords: acquired immune deficiency syndrome, PLWHA, Quality of life

Affiliasi penulis: 1. Prodi Magister Keperawatan, Universitas Andalas, Padang, Indonesia. 2. Bagian IImu Penyakit Dalam, Fakultas Kedokteran, Universitas Andalas, Padang, Indonesia. 3. Rumah Sakit Umum Pusat Dr M Djamil Padang.

Korespondensi: arina_widyamurni@yahoo.com Telp: 082284584110 


\section{PENDAHULUAN}

Infeksi Human Immunodeficiency Virus (HIV) / Acquired Immune Deficiency Syndrome (AIDS) merupakan salah satu masalah kesehatan masyarakat yang serius yang dapat menimbulkan masalah yang cukup luas yakni meliputi masalah fisik, sosial dan emosional. ${ }^{1}$ HIV adalah penyebab terjadinya epidemi terhadap kesehatan masyarakat yang telah berdampak kepada jutaan orang di seluruh dunia. Padahal kemajuan medis telah menurunkan angka kematian AIDS sebesar 42\% sejak tahun $2004{ }^{2}$

Peningkatan yang signifikan untuk kasus HIVAIDS juga terjadi di Indonesia dimana tercatat sebanyak 30.395 kasus untuk kejadian HIV pada tahun 2015 dan mengalami peningkatan menjadi 41.250 kasus HIV pada tahun 2016. ${ }^{3}$ Kasus HIV AIDS di Sumatera Barat pada tahun 2015 tercatat sebanyak 243 kasus dan pada tahun 2017 sebanyak 1.680 kasus. merupakan bagian dari Provinsi Sumatera Barat memegang angka tertinggi untuk kasus HIV AIDS, tercatat sebanyak 745 kasus pada tahun $2017 .{ }^{4}$

$$
\text { Studi yang dilakukan Kusuma (2018) }
$$
menunjukkan bahwa kepatuhan minum obat mempengaruhi kualitas hidup ODHA. ${ }^{5}$ Penelitian yang dilakukan Mutabazi-Mwesigire et al (2015) bahwa jumlah CD4 juga mempengaruhi kualitas hidup ODHA. ${ }^{6}$ Kepatuhan minum obat yang baik adalah meminum obat sesuai yang diresepkan dan kesepakatan antara pasien dan tenaga kesehatan. Kepatuhan minum obat yang buruk termasuk melewatkan dosis atau menggunakan obat secara tidak tepat (minum pada waktu yang salah atau melanggar pantangan makanan tertentu). ${ }^{7}$ Resiko kegagalan terapi terjadi jika pasien sering lupa minum obat. Untuk mencapai efek terapi dengan menekan replikasi virus yang optimal diperlukan tingkat kepatuhan setidaknya $95 \%{ }^{8}$

Penelitian ini bertujuan untuk menganalisis hubungan kepatuhan minum obat dan jumlah CD4 terhadap kualitas hidup orang dengan HIV AIDS (ODHA) di Poliklinik Voluntary Counseling and Testing RSUP Dr. M. Djamil Padang.

\section{METODE}

Penelitian ini merupakan studi analitik dengan pendekatan cross sectional. ${ }^{9}$ Populasi dalam penelitian ini adalah seluruh ODHA yang melakukan kontrol di poliklinik VCT RSUP Dr. M. Djamil Padang berjumlah 320 orang. Sampel penelitian ini adalah 100 ODHA yang melakukan kontrol di poliklinik VCT RSUP. DR. M. Djamil Padang yang memenuhi kriteria inklusi. Pengambilan sampel dalam penelitian ini dilakukan dengan metode probability sampling melalui simple random sampling yaitu metode pengambilan sampel secara acak sederhana dengan asumsi bahwa karakteristik tertentu yang dimiliki oleh populasi tidak dipertimbangkan dalam penelitian. ${ }^{10}$

Alat pengumpulan data untuk cross sectional dilakukan dengan menggunakan kuesioner sebagai instrument penelitian. ${ }^{11}$ Kuesioner digunakan untuk mendapatkan data variabel independen dan dependen yaitu: Kusioner kualitas hidup yang telah dimodifikasi dari WHOQOL-HIV BREF oleh Kusuma yang terdiri dari 31 pertanyaan, ${ }^{5}$ Kepatuhan minum obat diukur dengan menggunakan Pengkajian Simplified selfreport measure of adherence Morisky, yang berjumlah sebanyak 4 item pertanyaan, dan untuk jumlah CD4 didapatkan dari studi dokumentasi terhadap status rekam medis pasien.

\section{HASIL}

Univariat

Ada 100 responden orang dengan HIV AIDS (ODHA) di Poliklinik voluntary counseling and testing RSUP Dr. M Djamil Padang hampir seluruh (78\%) responden berada dalam rentang usia dewasa awal (18- 40 tahun), hampir seluruh (84\%) responden berjenis kelamin laki- laki, setengahnya $(50 \%)$ dengan tingkat pendidikan sedang (lulusan SMA), (72\%) patuh minum obat, $(64 \%)$ responden memiliki CD4 > 200.

Hasil penelitian menunjukkan bahwa hampir seluruh $(79 \%)$ ODHA memiliki kualitas hidup baik dan sebagian kecil (21\%) ODHA dengan kualitas hidup kurang baik. 


\section{Bivariat}

Tabel 1. Kepatuhan minum obat dan jumlah CD4 dengan kualitas hidup ODHA di Poliklinik Voluntary Counseling and Testing RSUP Dr. M. Djamil Padang tahun 2019

\begin{tabular}{|c|c|c|c|c|c|c|}
\hline \multirow{3}{*}{ Variabel } & \multicolumn{4}{|c|}{ Kualitas hidup } & \multirow{3}{*}{$\mathbf{p}$} & \multirow{3}{*}{ OR } \\
\hline & \multirow{2}{*}{$\begin{array}{c}\text { Baik } \\
\mathbf{f}\end{array}$} & \multicolumn{3}{|c|}{ Kurang baik } & & \\
\hline & & $\%$ & $f$ & $\%$ & & \\
\hline \multicolumn{7}{|c|}{ Kepatuhan } \\
\hline Patuh & 61 & 84,7 & 11 & 15,3 & & 3,081 \\
\hline \multicolumn{7}{|l|}{ Tidak } \\
\hline \multirow[t]{2}{*}{ patuh } & 18 & 64,3 & 10 & 35,7 & 0,040 & $1,128-$ \\
\hline & & & & & & 8,415 \\
\hline \multicolumn{7}{|c|}{ Jumlah CD4 } \\
\hline >200 & 55 & 85,9 & 9 & 14,1 & & 3,056 \\
\hline \multirow[t]{3}{*}{$\leq 200$} & & & & & 0,044 & \\
\hline & 24 & 66,7 & 12 & 33,3 & & $1,137-$ \\
\hline & & & & & & 8,210 \\
\hline
\end{tabular}

Berdasarkan Tabel 1 dapat diketahui bahwa hasil analisis hubungan antara kepatuhan minum obat dengan kualitas hidup ODHA dari 100 responden ODHA yang tidak patuh 61 orang $(84,7 \%)$ memiliki kualitas hidup yang baik dengan nilai $p=0,048$ $(p<0,05)$ yang berarti ada hubungan antara kepatuhan dengan kualitas hidup ODHA. Hasil analisis hubungan antara jumlah CD4 dengan kualitas hidup ODHA dari 100 responden ODHA dengan jumlah CD4>200 55 orang (85,9\%) memiliki kualitas hidup yang baik dengan nilai $p=0,044(p<0,05)$ yang berarti ada hubungan jumlah CD4 dengan kualitas hidup ODHA.

\section{PEMBAHASAN}

\section{Gambaran kualitas hidup ODHA di Poliklinik Voluntary Counseling and Testing RSUP Dr. M. Djamil Padang.}

Hasil penelitian menunjukkan bahwa hampir seluruh (79\%) ODHA memiliki kualitas hidup baik dan sebagian kecil (21\%) ODHA dengan kualitas hidup kurang baik. Hasil penelitian serupa juga didapatkan dari penelitian yang dilakukan oleh Lessa et al (2014). ${ }^{12}$ dimana sebagian besar responden menggambarkan kualitas hidupnya secara umum dalam kondisi baik yaitu sebanyak 7 orang $(63,6 \%)$, bahkan 2 orang responden (18,2\%) merasa kondisinya sangat baik, dan 2 orang lainnya (18,2\%) merasa biasa-biasa saja.
Menurut Cooper et al (2017), kualitas hidup terdiri dari berbagai dimensi yaitu dimensi fisik, psikologis, sosial, lingkungan, tingkat kemandirian dan spiritual. ${ }^{13}$ Penelitian yang dilakukan di Poliklinik Voluntary Counseling and Testing RSUP Dr. M. Djamil Padang didapatkan pada dimensi fisik, banyak responden yang menjawab jarang (22\%) yang merasa penyakitnya mencegah aktifitas, 33\% yang menjawab jarang yang merasa terganggu oleh masalah fisik yang berkaitan dengan infeksi HIV, 42\% responden memiliki energi yang cukup untuk beraktifitas dan 69\% responden menjawab puas dengan kualitas tidurnya. Hal ini menunjukkan bahwa sakit fisik tidak mengganggu istirahat dan tidur ODHA. ODHA masih bisa melakukan aktifitas dan masih aktif bekerja dimana ini juga terlihat dari karakteristik responden yang mayoritas bekerja.

Pada dimensi psikologis, didapatkan bahwa $32 \%$ responden sangat menikmati hidupnya, 53\% sangat baik kemampuannya dalam berkonsentrasi. Hanya $1 \%$ responden sama sekali tidak dapat menerima penampilan tubuhnya, $1 \%$ responden menyatakan tidak puas dengan dirinya sendiri dan $2 \%$ responden cukup sering merasa putus asa, sedih, gelisah dan depresi. Dilihat dari hasil persentase, menunjukkan bahwa ODHA bisa menikmati hidupnya seperti layaknya orang normal yang tidak terdiagnosa HIV/AIDS.

Pada dimensi sosial, 45\% responden merasa puas dengan hubungan pribadinya, $44 \%$ responden sangat diterima oleh orang yang dikenalnya, hanya $23 \%$ responden merasa cukup mendapatkan dukungan dari teman-temannya dan $4 \%$ tidak puas dengan kehidupan seksnya. Dukungan mental dan emosional tidak hanya diberikan kepada ODHA saja tetapi juga pada Orang Hidup Dengan HIV/AIDS (OHIDHA), karena status HIV/AIDS seringkali berujung pada stigma dan diskriminasi dikarenakan kurangnya pengetahuan mengenai masalah penyakit HIV/AIDS. OHIDHA juga diberikan konseling untuk tidak mengucilkan, menolak bahkan mengusir ODHA dalam keluarga. Perasaan empati yang yang diberikan OHIDHA akan berdampak positif bagi ODHA, ODHA akan merasakan hidupnya berarti karena mendapatkan dukungan dari keluarga dan lingkungan sosialnya, respon positif ini akan membuat ODHA 
dapat melanjutkan hidupnya tanpa ada rasa takut akan stigma dan diskriminasi. ${ }^{14}$

Pada dimensi tingkat kemandirian, didapatkan $51 \%$ responden merasa puas dalam kemampuannya untuk mendapatkan sesuatu. Hanya $10 \%$ responden merasa kurang puas dengan kemampuannya untuk melakukan aktifitas sehari-hari dan sebanyak $18 \%$ responden merasa kurang puas dengan kemampuan untuk bekerja.

\section{Hubungan kepatuhan dengan kualitas hidup ODHA di Poliklinik Voluntary Counseling and Testing RSUP Dr. M. Djamil Padang.}

Hasil penelitian menunjukkan bahwa sebagian besar (72\%) patuh selama pengobatan. Hasil penelitian ini senada dengan yang dilakukan oleh Saputro et al (2016) didapatkan bahwa hampir seluruh (92.9\%) ODHA patuh selama pengobatan. ${ }^{15}$

Berdasarkan analisis bivariat menunjukan bahwa dari 100 responden ODHA yang tidak patuh 61 orang (84,7\%) memiliki kualitas hidup yang baik dengan nilai $p=0,048 \quad(p<0,05)$ yang berarti ada hubungan antara kepatuhan dengan kualitas hidup ODHA. Kepatuhan merupakan salah satu faktor penting dalam keberhasilan terapi Anti Retro Virus (ARV). Resiko kegagalan terapi terjadi jika pasien sering lupa minum obat. Untuk mencapai efek terapi menekan replikasi virus yang optimal diperlukan tingkat kepatuhan setidaknya $95 \% .{ }^{16}$

Pada penelitian ini dapat dilihat dari 72 responden yang patuh, 61 orang memiliki kualitas hidup yang baik sedangkan 11 orang memiliki kualitas hidup kurang baik, sebagaimana diketahui kualitas hidup dinilai dari 6 dimensi, dimana dimensi fisik dan lingkungan memiliki hubungan bermakna dengan kepatuhan minum obat $A R V$, ini sesuai dengan penelitian yang dillakukan oleh Syahru bahwa ada hubungan signifikan antara dimensi fisik dan dimensi lingkungan pada kualitas hidup dengan kepatuhan minum obat ARV. ${ }^{17}$ Handayani et al (2017) yang menyatakan bahwa kepatuhan minum ARV adalah faktor positif dalam kualitas hidup ODHA pada dimensi fisik karena kontribusinya pada peningkatan jumlah CD4 secara pesat. $^{18}$ Dalam penelitian ini juga ditemukan 18 responden yang tidak patuh namun memiliki kualitas hidup yang baik, ini disebabkan karena pada penilaian kualitas hidup ada 4 dimensi lagi yang tidak ada hubungannya dengan kepatuhan minum obat yang memiliki nilai positif terhadap penilaian kualitas hidup ODHA yaitu dimensi sosial, dimana ODHA mengatakan selalu diterima oleh orangorang yang mengenalnya, selalu mendapatkan dukungan dari teman-temannya, pada dimensi spiritual, ODHA merasa tidak khawatir dalam menghadapi kematian, merasa hidupnya sangat berarti, pada dimensi psikologis didapatkan ODHA cukup dapat menikmati hidupnya, dapat menerima penampilan tubuhnya dan merasa puas terhadap dirinya sendiri. Dan pada dimensi kemandirian, ODHA mengatakan merasa puas dengan kemampuannya bekerja dan cukup baik kemampuannya dalam mendapatkan sesuatu.

\section{Hubungan jumlah CD4 dengan kualitas hidup ODHA di Poliklinik Voluntary Counseling and Testing RSUP Dr. M. Djamil Padang.}

Hasil penelitian menunjukkan bahwa sebagian besar (64\%) responden memiliki CD4 > $200 \mathrm{sel} / \mathrm{mm} 3$. Ini bisa disebabkan karena tingginya tingkat kepatuhan minum obat responden yaitu sebesar $72 \%$. Hasil penelitian ini senada dengan penelitian yang dilakukan oleh Liping et al (2015) dimana sebagian besar (83,88\%) ODHA memiliki jumlah CD4>200 $\mathrm{sel} / \mathrm{mm} 3 .^{14}$

Berdasarkan analisis bivariat menunjukkan bahwa dari 100 responden ODHA dengan jumlah CD4 $\leq 20055$ orang $(85,9 \%)$ memiliki kualitas hidup yang baik dengan nilai $p=0,044(p<0,05)$ yang berarti adanya hubungan yang signifikan antara jumlah CD4 yang lebih tinggi dengan kualitas hidup pada ODHA. Hasil penelitian ini sesuai dengan Theofilou (2013) di Klinik ART Selatan India Selatan menemukan bahwa skor QOL lebih rendah signifikan dengan jumlah CD4 yang lebih rendah. ${ }^{19}$ Betancur et al (2017) juga menyatakan adanya hubungan yang kuat antara jumlah CD4 dengan kualitas hidup ODHA, rendahnya jumlah sel CD4 pada ODHA memungkinkan beberapa infeksi oportunistik akan meningkat. Akhirnya kualitas hidup dipertaruhkan. Pemeriksaan CD4 berguna untuk memulai, mengontrol dan mengubah regimen ARV 
yang diberikan. Selain itu, pemeriksaan CD4 dilakukan untuk melihat apakah terdapat perubahan jumlah CD4 setelah mendapatkan ARV. Jika jumlah CD4 tidak dikontrol maka akan menyebabkan munculnya berbagai jenis infeksi opportunistik karena sistem kekebalan tubuh yang semakin menurun yang berpengaruh pada semakin banyaknya pengobatan yang diterima penderita. Dengan mengetahui jumlah CD4 sebelum dan selama menjalani terapi ARV maka dapat dilihat keberhasilan atau kegagalan dari terapi tersebut. ${ }^{20}$

Pada analisis bivariat didapatkan 24 dari 36 ODHA yang memiliki jumlah CD4 dibawah 200 masih dalam rentang kualitas hidup yang baik, ini disebabkan karena pada dimensi psikologis, dimensi sosial, sprirual, lingkungan mereka memiliki nilai yang baik sehingga membuat ODHA tersebut berada pada rentang kualitas hidup yang baik.

\section{SIMPULAN}

Terdapat hubungan yang bermakna dengan $\mathrm{p}<$ 0,05 antara kepatuhan minum obat dan jumlah CD4 terhadap kualitas hidup orang dengan HIV/AIDS di Poliklinik Voluntary Counseling and Testing RSUP Dr. M. Djamil Padang. Diharapkan kepada petugas kesehatan agar selalu memberikan edukasi tentang pentingnya patuh minum obat ARV secara rutin, sehingga jumlah CD4 di dalam darah berada dalam batas normal sehingga ODHA memiliki fisik yang sehat akibatnya berdampak pada kualitas hidupnya.

\section{UCAPAN TERIMAKASIH}

Terimakasih kepada tim medis dan paramedis RSUP Dr. M. Djamil Padang, khususnya ruang Poliklinik VCT dan seluruh pihak yang terlibat dalam memberikan motivasi, bimbingan dan kerjasama dalam penelitian ini.

\section{DAFTAR PUSTAKA}

1. Jadhav PS, Laad PS, Chaturvedi RM. Quality of life factors affecting quality of life in people living with HIV / AIDS in an urban area. International Journal Community Med Public Health. 2017;4(8):3031-6.
2. UNAIDS. UNAIDS Global statistics 2018. 2018;(July):1-5 (Diakses Januari 2019).

Tersedia dari: http://www.unaids.org/sites/default

/files/media asset/UNAIDS FactSheet en.pdf

3. Direktorat Jenderal Pencegahan dan Pengendalian Penyakit. Laporan perkembangan HIV/AIDS 7 penyakit menular seksual (PIMS) triwulan I tahun 2017. Jakarta: Kementerian Kesehatan RI; 2017.

4. Dinas Kesehatan Kota (DKK) Padang. Laporan HIV AIDS TW 2017-2018. Padang: DKK; 2018.

5. Kusuma H. Hubungan antara depresi dan dukungan keluarga dengan kualitas hidup pasien HIV/AIDS yang menjalani perawatan. Jurnal IImu Keperawatan Medial Bedah Mei 2018;1(1):1-43.

6. Mutabazi-Mwesigire D, Katamba A, Martin F, Seeley $\mathrm{J}, \mathrm{Wu}$ AW. Factors that affect quality of life among people living with HIV attending an urban clinic in Uganda: A cohort study. PLoS One. 2015;10(6):1-21.

7. Yuliandra Y, Nosa US, Raveinal R, Almasdy D. Terapi antiretroviral pada pasien HIV/AIDS di RSUP. Dr. M. Djamil Padang: kajian sosiodemografi dan evaluasi obat. Journal Sains Farm Klin. 2017;4(1):1.

8. Sugiharti S, Yuniar Y, Lestary H. Gambaran kepatuhan orang dengan HIV-AIDS (ODHA) dalam minum obat ARV di kota Bandung, Provinsi Jawa Barat, tahun 2011-2012. J Kesehat. 2014;1-11.

9. Notoadmodjo. Metodologi penelitian dalam kesehatan. Jakarta: Salemba medika; 2010.

10. Dharma KK. Metodologi penelitian keperawatan panduan melaksanakan dan menerapkan hasil penelitian. Jakarta: Trans Info Media; 2015. hIm.71-197.

11. Sugiyono. Metode penelitian kuantitatif, kualitatif dan R\&D. Jakarta: Trans Info Media; 2017.

12. Lessa T, Oliveira DC De, Marcos A, Gomes T, Formozo GA. Quality of life and people living with AIDS: relationship with sociodemographic and health aspects. J Revista latino-americana de enfermagem 1. 2014;22(4):582-90. 
13. Cooper V, Clatworthy J, Harding R, Whetham J, Brown A, Leon A, et al. Measuring quality of life among people living with HIV: A systematic review of reviews. Health Qual Life Outcomes. 2017;15(1): 220.

14. Liping $M$, Peng $X$, Haijiang L, Lahong J, Fan L. Quality of life of people living with HIV/ AIDS: A Cross-sectional study in zhejiang province, China. PLoS One. 2015;10(8):1-14.

15. Saputro Al, Kaunang WP, Joseph WB. Faktor faktor yang berhubungan dengan kepatuhan ODHA dalam menjalankan terapi ARV di RSPAD Gatot Soebroto Jakarta Pusat. Journal Heal. 2016;8(3):1-10.

16. Ubra RR. Faktor-faktor yang berhubungan dengan kepatuhan pengobatan minum ARV pada pasien HIV di Kabupaten Mimika-Provinsi Papua. 2012; E-Jurnal Medika Udayana. 2018;7(9):353-62.
17. Syahru. Hubungan kepatuhan ART satu bulan terakhir dengan kualitas hidup pasien HIV/AIDS di RSUP Dr. Soetomo Surabaya. Jurnal Unair. 2016;10(8):1-14.

18. Handayani F, Dewi FST, Dewi FST. Faktor yang mempengaruhi kualitas hidup orang dengan HIV/AIDS (ODHA) di Kota Kupang. Kedokt Masy. 2017;33(11):509.

19. Theofilou P. Quality of life: Definition and measurement. Eur Journal Psychol. 2013;9(1):150-62.

20. Betancur MN, Lins L, Oliveira IR de, Brites C. Quality of life, anxiety and depression in patients with HIV/AIDS who present poor adherence to antiretroviral therapy: a cross-sectional study in Salvador, Brazil. Brazilian Journal Infect Dis. 2017;21(5):507-14. 